\title{
UNDERSTANDING GOVERNANCE MECHANISMS IN SMALL AND MEDIUM FAMILY FIRMS IN LATIN AMERICA
}

\author{
ENTENDIENDO LOS MECANISMOS DE GOBIERNO EN LAS EMPRESAS FAMILIARES \\ PEQUEÑAS Y MEDIANAS DE AMÉRICA LATINA
}

\author{
Isabel C. Botero ${ }^{\mathrm{a}}$ Fernando Sandoval Arzaga ${ }^{\mathrm{b}} \cdot$ Kirsten Brøndsted Bullock $^{\mathrm{c}}$ \\ Classification: Empirical paper - research \\ Received: October 2, 2020 / Revised: December 10, 2020; March 20, 2021 / Accepted: April 16, 2021
}

\begin{abstract}
Governance mechanisms help manage, direct, and control people, resources, and the interests of those involved in a firm. In family firms, understanding the use of governance mechanisms is particularly important given their relationship with the sustainability of the family and the business. Even though we know a great deal about family business governance in North America and Europe, we still know very little regarding the use of governance mechanisms in small and medium (SME) family firms in Latin America, nor do we know whether the use of governance mechanisms impacts financial performance. To address these gaps, this paper presents the results of a survey completed by 2287 representatives of family business SMEs from 24 Latin American countries. Participants indicated the likelihood of their using different governance mechanisms and responded to questions concerning their businesses. Our results indicate that the small and medium Latin American family firms in our study were not very likely to use formal business and family governance mechanisms, however, the use of formal business governance mechanisms was related to financial performance. The implications of these results for research and practice are discussed.
\end{abstract}

Keywords: Governance in family firms, governance mechanisms, Latin American family firms, family firm performance.

\section{Resumen}

Los mecanismos de gobierno ayudan a administrar, dirigir y controlar a las personas, los recursos y los intereses de quienes participan en una empresa. En las empresas familiares, comprender el uso de los mecanismos de gobierno es de especial importancia dada su relación con la sostenibilidad de la familia y la empresa. A pesar de que sabemos bastante sobre el gobierno de la empresa familiar en América del Norte y Europa, todavía sabemos muy poco sobre el uso de mecanismos de gobierno en empresas familiares pequeñas y medianas (PYME) en América Latina, y si el uso de mecanismos de gobierno afecta el desempeño financiero. Para abordar estas brechas, este artículo presenta los resultados de una encuesta en la que participaron 2287 representantes de PYMES de empresas familiares de 24 países de América Latina. Los participantes indicaron su probabilidad de utilizar diferentes mecanismos de gobierno y respondieron preguntas sobre sus negocios. Nuestros resultados indican que las pequeñas y medianas empresas familiares latinoamericanas de este estudio no tenían muchas probabilidades de utilizar mecanismos formales de gobierno empresarial y familiar, sin embargo, el uso de estos mecanismos estaba relacionado con el desempeño financiero. Se discuten las implicaciones de estos resultados para la investigación y la práctica.

Palabras clave: gobierno en empresas familiares, mecanismos de gobierno, empresas familiares latinoamericanas, desempeño de empresas familiares.

a Family Business Center. University of Louisville, Entrepreneurship Department. Louisville, KY, USA. E-mail: Isabel.botero@louisville.edu

b Center for Entrepreneurial Families. Tecnológico de Monterrey. Estado de Mexico, Mexico. E-mail: fsandoval@tec.mx

c College of Business. University of Louisville, Louisville, KY, USA. E-mail: kirsten.bullock@louisville.edu 


\section{Introduction}

Family firms ${ }^{1}$ are the dominant form of organisation in Latin America (Müller et al., 2019; Vazquez et al., 2020) and around the world (Colli, 2003; Howorth et al., 2010). Even though these firms strive for the continuity of the family and the business, they are constantly faced with challenges that arise from the complexity of managing the dynamics and the sometimes-conflicting goals between the family and the business systems (Gómez-Mejía et al., 2007; Pieper et al., 2013). Given the potentially negative consequences that these challenges can bring, extensive literature has developed to help business families understand the tools that are available to meet these challenges and enhance their continuity (See De Massis et al., 2012; Yu et al., 2012 for a comprehensive reviews). Academics and practitioners both suggest that governance is one of the most important resources available for managing the competing demands of the family and business systems (Aguilera \& Crespi-Caldera, 2012; Brenes et al., 2006; Suess, 2014).

In the broadest sense governance describes the mechanisms that are used to ensure that the actions and behaviours of the stakeholders are consistent with the goals of the owners (Aguilera \& Jackson, 2003). It helps determine how to best use and deploy resources, and how to resolve conflict among the different stakeholders (Daily et al., 2003). Although we have a general understanding of governance in family firms, most of this knowledge is based on data from North America and Europe (De Massis et al., 2012). This can be problematic given the role that the cultural context can play in how family businesses operate and make decisions (Peng et al., 2018; Sharma \& Chua, 2013). Previous research has indicated that family businesses in Latin America are different in the way that they organise themselves (Botero \& Velez, 2019; Lansberg \& Perrow, 1991; Vazquez et al., 2020), and in the way they make decisions (Botero \& Gomez Betancourt, 2017). However, even though published research about Latin American family firms has been increasing in recent years (e.g., Briano-Turrent \& Poletti-Hughes, 2017; Nicholson, 2015; Müller et al., 2019; Parada et al., 2016, Vazquez et al., 2020), we still know very little regarding the use of governance mechanisms by family firms in this region, or regarding the use of different governance mechanisms in the financial performance of the firm (Botero \& Gomez Betancourt, 2017; Nordqvist et al., 2011). Given the importance that governance mechanisms have for family firms, it is important to understand whether their use is prevalent, and recognize the effect

1 In this paper we use family firm, family-owned business, and family business as interchangeable terms. that governance mechanisms can have in the financial performance of family firms.

To address these concerns, this project was designed with two goals in mind. First, we were interested in understanding the likelihood of small and medium (SME) family firms in Latin America using family and business governance mechanisms. Given that most of our knowledge regarding governance in Latin American family firms comes from data collected from large family firms, we wanted to better understand the practices of family-owned SMEs, and appreciate whether they mirrored their larger counterparts. Second, we also wanted to explore the relationship between the use of governance mechanisms and the financial performance of family firms. Based on agency theory (Jensen, 1986; Jensen \& Meckling, 1976) and the work of Aguilera and Crespi-Cladera (2012) we contend that, given that governance mechanisms help monitor and control the different strategic goals of owners, the incorporation of governance mechanisms into family firm SMEs is likely to enhance performance because it allows for managers and owners to better determine how and when resources will be deployed. To achieve these goals, we conducted a survey with 2287 family firm representatives from 24 countries. Participants were individuals who attended family business classes or extension programmes offered on a semester basis between 2014 and 2018. The findings indicate that the firms in this study were not likely to use formal governance mechanisms. Nonetheless, using formal business mechanisms resulted in a higher financial performance of the firm.

Our paper proffers three important contributions to the literature. First, this is one of the few empirical studies that explores the use of formal governance mechanisms in small and medium family firms in Latin America. This is important because previous knowledge is based on results from publicly traded family firms, which are likely to behave in a very different way. Second, our study extends our previous understanding of governance in Latin American Family firms by exploring the use of formal family governance mechanisms and their potential impact on financial performance. Previous works have primarily explored business governance (Lagos Cortes \& Botero, 2016). Finally, the results of this study continue to increase our understanding regarding factors that influence heterogeneity in family firms. Below, we provide a description of the rationale for the study, the methodology used for data collection, the results obtained, and the implications of these results in our understanding of Latin American small and medium family firms and their continuity. 


\section{Governance in Family Firms}

A primary goal of governance in family firms is to ensure the continuity and viability of the family and the business across generations. However, there are constant challenges that make achieving these goals difficult (Gersick et al., 1997). Researchers argue that one of the reasons continuity and business viability in the family business context can be challenging is that conflicts can emerge when family and business mix (Pieper et al., 2013). Family and business systems have different logics and norms that can affect the interaction between these two systems (Davis, 1983; Ward, 1997). On one hand, families are guided by egalitarian logics in which all members should be treated equally regardless of their capabilities (Davis, 1983). On the other hand, businesses are guided by the logic of meritocracy (Davis, 1983). Meritocracy suggests that those who show greater capabilities, effort, and work should be rewarded, while those who do less and are not as capable should be removed from the system. When these two logics contradict each other, the types of conflict situations that they generate can affect both family (i.e., family dynamics) and business (i.e., financial performance) (Eddleston \& Kellermanns, 2007; Kellermanns \& Eddleston, 2004; Olson et al., 2003). This, in turn, can harm the continuity of the family and the business. One of the ways to prevent and/or manage the potential conflicts that may occur in a family firm is by developing and implementing formal governance mechanisms (Aronoff et al., 1998; Gallo \& Tomaselli, 2006; Ward, 2000). This has sparked an interest in further understanding how corporate governance can help family firms.

In the broadest sense, corporate governance describes the structures, processes, and policies organisations use to manage, direct, and control people, resources, and the interests of those involved in a firm (Aguilera \& Jackson, 2010). The general assumption is that by implementing formal governance practices organisations can enhance their future success. In the context of family firms, governance is often connected to the success and sustainability of the family and the business (Miller \& Le Breton-Miller, 2006; Steier et al., 2015; Suess 2014; Villalonga et al., 2015). The family's involvement in a firm introduces important considerations and complexities to our understanding of corporate governance (Cadbury, 2000; Pieper, 2003). In particular, the inclusion of the family in the business system requires the creation of formal structures, policies, and processes that enable parallel thinking to support, integrate, and balance the interests of the family, the business, and its owners (Carlock \& Ward, 2001). Thus, research suggests that the corporate governance of family firms needs to include formal structures, processes, and policies that describe how elements of the family, the ownership, and the business systems interact with each other (Pieper, 2003).

To date, corporate governance is the most studied topic within family business literature (De Massis et al., 2012; Debicki et al., 2009). This research has been focused on exploring the different types of formal policies and practices that are available, the implementation of these practices in the family business context, and the effects that governance policies and structures can have on the family and on the business (Gersick \& Feliu, 2014). Researchers suggest that the continuity of a firm is linked to the structures and dynamics of the family, the creation and implementation of formal governance mechanisms, and the family firm's ability to cope with disruptions (Olson et al., 2003). This paper concentrates on formal family and business governance mechanisms. Formal family governance outlines the mechanisms that help the business family organise and manage the relationships between family and business (Berent-Braun \& Uhlaner, 2012), family and ownership (Montemerlo \& Ward, 2011), and family and management (Mustakallio et al. 2002). The purpose of these formal governance mechanisms is to explicitly articulate and clearly outline the rewards and demands that are linked to being part of the family business, to clearly identify the opportunities for family members who are involved in the business, and to facilitate the flow of trustworthy information among family members (Gersick \& Feliu, 2014; Suess, 2014). Family governance is voluntary and is likely to vary greatly among family firms (Jaffe \& Lane, 2004). Formal business governance describes the policies and procedures that relate to the Board of Directors, the CEO, and the top management team (Suess, 2014). It can also include aspects of ownership such as the ownership council, shareholder meetings, and the family office. The purpose of these formal mechanisms is to ensure that the actions of organisational stakeholders are consistent with the goal of the business (Aguilera \& Jackson, 2010).

Formal governance mechanisms can play a very important role for family firm sustainability (Stafford et al., 1999). In the family system, governance mechanisms help prevent dysfunctional conflicts that can escalate to the destruction of the business, and help the family organise itself and its relationship with the business (Olson et al., 2003). On the business side, good governance practices can help family firms deal with the agency problems that they may face with the involvement of the family in the business (Villalonga et al., 2015), which can affect the performance of the firm (Berent-Braun \& Uhlaner, 2012). Thus, it is important to understand whether family firms use these practices to be able to anticipate the types of 
challenges that they could face when managing the overlap of the family and the business systems.

Even though governance has been recognised as an important topic in family busines research (Gersick, 2015; Morck \& Steier, 2005), there are several areas that remain understudied (Berrone et al., 2012). One of these areas is a better understanding of the use of governance in family businesses around the world. Thus, this paper focuses on understanding governance in Latin American family firms.

\section{Governance in Latin American Family Firms}

The Latin American region is important because of its size (i.e., more than 600 Million people live in this region), its relevance in the economic market due to its control over important commodities (i.e., iron, copper, zinc), and its manufacturing capabilities (Nicholson, 2011). Family firms are the dominant form of organisation in this part of the world (Müller et al., 2019), and represent close to $90 \%$ of the firms in Latin American countries (IFERA, 2003). Although research regarding Latin American family firms has been carried out since the early 1990s (see: Lansberg \& Perrow, 1991), we still have a very limited understanding of the general characteristics of family firms in Latin America, and how they are different from family firms in other parts of the world. There are at least two reasons for this limited understanding. First, in this part of the world, the great majority of family firms are privately owned (Lansberg \& Perrow, 1991). This private nature makes data collection and access more difficult. Second, most of the knowledge that is published about family firms from this region has been published in Spanish, with very little impact in international journals (López-Fernández et al., 2017). However, since 2010, there has been an increase in the articles published about Latin American Family firms in international journals (For examples see Brenes et al., 2011; Husted \& De Sousa-Filho, 2019; Vasquez et al., 2020).

There are two areas that have dominated the study of governance mechanisms in Latin American family firms (Lagos Cortes \& Botero 2016). The first area explores the governance mechanisms used within the business system (i.e., characteristics of Top Management Teams (TMT), the effects of TMT on organisational processes, the characteristics of boards and the effects of boards on performance). This research has found that TMT and board composition affects the performance of a family firm (Castrillo Lara \& San Martín Reyna, 2007; López Vergara et al., 2011; Machuga \& Teitel, 2009; Watkins Fassler \& Dávila Delgado, 2012). The second area focuses on understanding governance within the ownership system. Research in this area has focused on understanding the choice of ownership structure and the effects of ownership choices on different aspects of the firm. Findings in this area indicate that the context influences ownership and voting rights used in a family business (Saito \& Di Miceli da Salveira, 2010, Santiago-Castro \& Brown, 2007). Additionally, the findings sustain that family ownership enhances performance and influences the quality and transparency of financial information (Espinosa Aguilo \& Espinoza Aguilo, 2012; Sáenz-Gonzalez \& García-Meca, 2014). More recently, Vasquez et al. (2020) complement our understanding of the use of governance mechanisms by suggesting that there are three large clusters (i.e., models) that describe the governance configuration of large Latin American Family firms. The exported governance model describes organisations whose governance model resembles characteristics of family firms from Anglo-America and continental Europe which favour the independence of the board and non-family management. The super familial governance model favours family control over the board and the top management team. The hybrid model favours the family influence on the board and on management, and the family controls the ownership of the firm.

Even though the majority of family firms in Latin America are small and medium enterprises (i.e., those with less than 500 employees; OECD.org), most of our knowledge about family business governance in this region comes from large, primarily publicly traded, family firms (Lagos Cortes \& Botero 2016). However, 99.5\% of all the businesses in Latin America are small and medium sized enterprises (OECD.org). Publicly traded firms differ greatly from small and medium family firms in that they have different responsibilities in their reporting requirements, they have different incorporation requirements, and they have different responsibilities towards their stockholders. Thus, the governance mechanisms used by large corporations are likely to be very different from those used by small and medium family firms. Given this disparity, we set forth the following research question:

RQ1: How likely are Latin American small and medium family firms to use business and family governance?

\section{Family Firm Governance and Performance}

The relationship between corporate governance and performance has intrigued researchers for many years. One of the theories that has been used to explain the impact that governance can have on the performance of a firm is agency theory (Jensen \& Meckling, 1976). The central premise of this theory suggests that managers and owners may have competing goals. Thus, managers may make 
decisions and engage in actions that are inconsistent with the owners' goals (i.e., maximising wealth; Daily et al., 2003). This creates problems between owners (i.e., principles) and managers (i.e., agents) that could lead to inefficiency and financial loss. Although family ownership can diminish the main agency problem (i.e., the conflict of interests between owners and managers), there are other agency problems that come to light by having the family involved in a business (Schulze et al., 2001; Villalonga et al., 2015; Zellweger \& Kammerlander, 2015). Thus, scholars have suggested that one of the ways that family business owners can diminish these agency problems is through the implementation of different governance mechanisms within the family and business systems (Schulze et al., 2001; Villalonga et al., 2015; Zellweger \& Kammerlander, 2015).

Corporate governance provides guidelines regarding how organisational resources will be used and deployed to achieve the goals of owners and provides guidelines with reference to how conflict among organisational stakeholders will be managed (Chrisman et al., 2018). Thus, the implementation of governance mechanisms within family firms is likely to enhance the strategic direction of the firm and ensure a "dynamic equilibrium" that provides essential resources to the family firm among the stakeholders (Chrisman et al., 2018). Both of these factors will diminish inefficiencies and enhance the performance of a family firm (Miller \& Le Breton Miller, 2006). Previous findings support the positive influence that family governance mechanisms have on the performance of family firms (Berent-Braun \& Uhlaner, 2012). The implementation of family governance practices enhances family unity (Uhlaner, 2006), helps promote the shared vision of the family, role clarity and responsibilities, clarifies conflict management procedures, and enhances the business family relationships (Carlock \& Ward, 2001; Gersick et al., 1997). Therefore, implementing family governance mechanisms is likely to diminish the potential effects that negative tensions in the family might have on the business, indirectly helping the company to better use its resources to enhance performance. Similarly, the implementation of business governance can help the family firm enhance the alignment and balance of interests among the different stakeholders which can impact the financial performance of the family firm (Brenes et al., 2011; Chrisman et al., 2004; Chrisman et al., 2018). Based on this idea, and consistent with the principles of agency theory, we sustain that the implementation of governance mechanisms serves as a way to align the goals of family owners, with the goals of the family and the business. Having greater alignment in goals clarifies the expectations and roles of all stake- holders. By doing this, the owners have the capacity to monitor each other to ensure that the goals of the family and the business can be achieved. Continuous monitoring, in turn, ensures the best use and deployment of resources which can translate into better financial performance. Based on this logic, we hypothesise that:

H1: The use of formal family governance mechanisms will be positively related to family business financial performance.

H2: The use of formal business governance mechanisms will be positively related to family business financial performance.

\section{Method}

\section{Sample and Procedure}

A total of 2,287 individuals from 24 countries participated in our study. Eighty-seven percent of the respondents were family members that were then working in their businesses. Their roles included president of the board $(9 \%)$, CEO (36\%), area manager (22\%), employee (12\%) or another role $(21 \%)$. They represented companies that varied in age from 3 to 164 years of age, and represented service $(38 \%)$, manufacturing $(27 \%)$, and retail $(35 \%)$ industries. Seventy-six percent of these companies had 50 or fewer employees and $57 \%$ had sales of less than three hundred thousand dollars. Regarding the generation that was in control of the business, $71 \%$ characterised themselves as a first-generation family business, $26 \%$ characterised themselves as second generation, and $3 \%$ were in the third generation or beyond. Although the majority of companies $(51 \%)$ were controlled by their founders, they all had at least one other family member that played an active role in the firm.

Data in this study were collected from members of family businesses that participated in family business extension programmes (face to face classes) or courses offered to family businesses and college students (i.e., Massive open online courses and family business classes). These individuals were invited to participate in an online survey on the practices of family firms. The invitation came via email after they had completed the course. The e-mail described the study and provided a link to participate in a survey. When participants activated the participation link, they were sent to a website designed for the study and asked to respond to a set of questions about themselves, the company they represented, the family that was in control of the business, and their family and business practices. Participants took between 10 and 15 minutes to complete the survey. Participation was 
voluntary, and individuals could withdraw from the survey at any time without any repercussion. In exchange, those who completed the survey received a report that provided information about their company in comparison with those of other respondents. All the data was collected in Spanish.

\section{Measures}

All data for this project was collected using a 5 pointLikert Scale ( $1=$ strongly disagree, $5=$ strongly agree). Family governance was measured with four items that asked respondents to indicate the level of agreement with statements indicating whether the family has a formal family council, written policies to manage the businessfamily relationship, formal stock transfer criteria, or conflict management policies. These items were aggregated to create a family governance average score (Cronbach's $\alpha=$ .78). Business governance was determined with four items that measured the presence of written policies for business procedures, a business board, a formal management team, and a written business plan. These items were combined to create an average score for business governance
(Cronbach's $\alpha=.80$ ). Finally, we measure financial performance by requesting respondents indicate the level of sales of the family business in dollars. Respondents replied via the following options: (1) Less than \$299,999 USD, (2) between $\$ 300,000$ and \$7.49 MM USD, (3) between, \$7.5 MM and \$19.99 MM USD, (4) between $\$ 20$ and \$49.99 MM USD, (5) between \$50 MM USD and \$99.99 MM USD, (6) between \$100 MM and \$500 MM USD, (7) More than \$500 MM USD.

We also analysed important controls. Industry was assessed by asking respondents to select whether the company was involved in service, manufacturing, or retail. We created two dummy variables to include in the analysis. We measured the company age by inquiring for the year in which the company was founded and determining the age in years from 2020. To assess size, we asked participants to relate the number of employees they had. The response options were: (1) 0 to 10 , (2) 11 to 50, (3) 51 to 250 , (4) more than 250 . Finally, we also assessed whether the family business was controlled by the founder or not. Table 1 provides the descriptive statistics for each country.

Table 1. Descriptives Based on Country

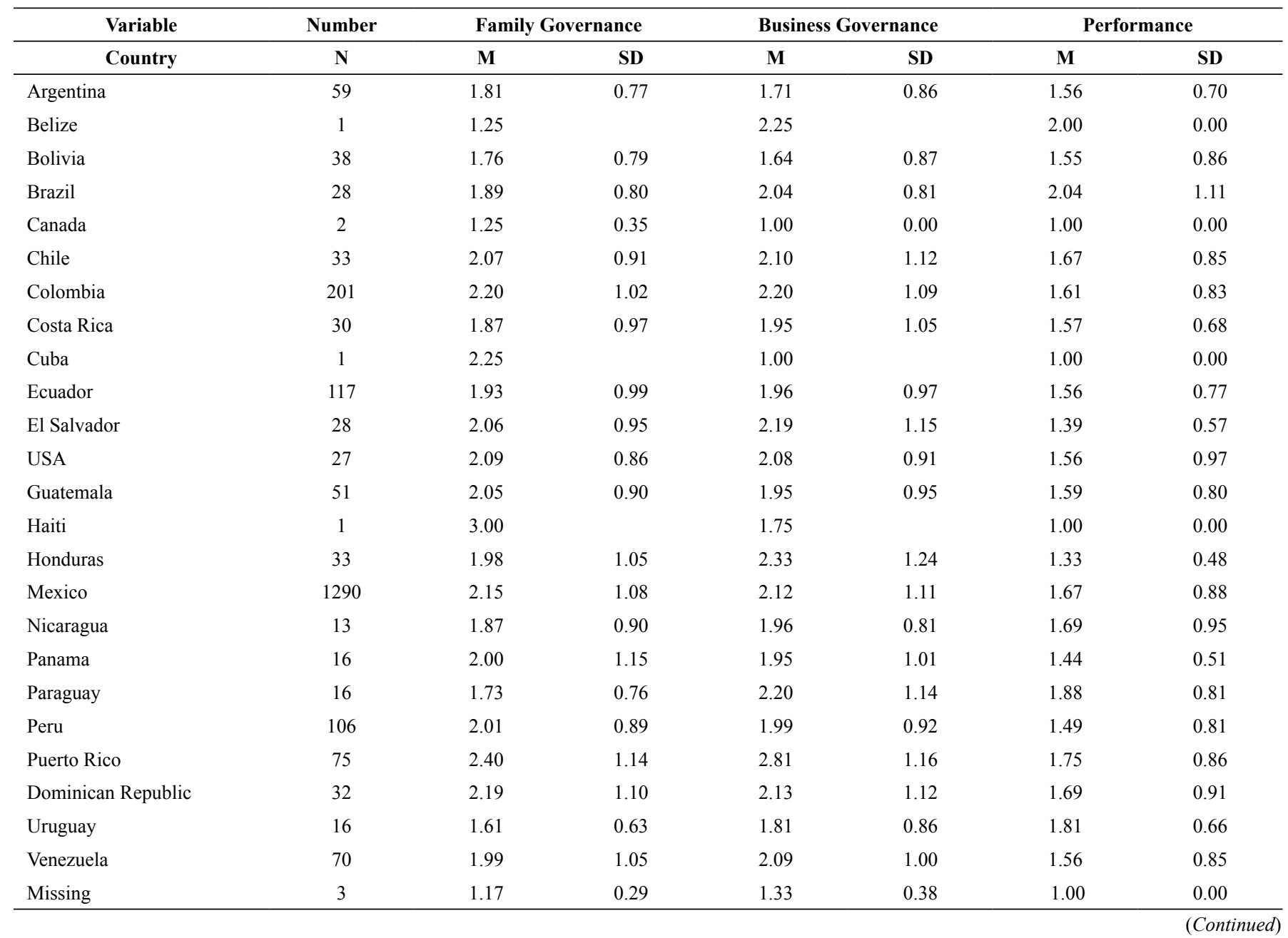




\begin{tabular}{|c|c|c|c|c|c|c|c|}
\hline \multirow{2}{*}{$\begin{array}{l}\text { Variable } \\
\text { Country }\end{array}$} & \multirow{2}{*}{$\begin{array}{c}\text { Number } \\
\mathrm{N}\end{array}$} & \multicolumn{2}{|c|}{ Founder Control } & \multicolumn{2}{|c|}{ Company Age } & \multicolumn{2}{|c|}{ Employees } \\
\hline & & $\mathbf{M}$ & SD & M & SD & M & SD \\
\hline Argentina & 59 & 0.47 & 0.50 & 0.34 & 0.48 & 1.69 & 0.84 \\
\hline Bolivia & 38 & 0.58 & 0.50 & 0.37 & 0.49 & 1.71 & 0.84 \\
\hline Brazil & 28 & 0.46 & 0.51 & 0.18 & 0.39 & 2.25 & 1.18 \\
\hline Colombia & 201 & 0.46 & 0.50 & 0.27 & 0.44 & 1.72 & 0.90 \\
\hline Costa Rica & 30 & 0.53 & 0.51 & 0.37 & 0.49 & 1.80 & 0.96 \\
\hline Cuba & 1 & 1.00 & & 0.00 & & 1.00 & \\
\hline Ecuador & 117 & 0.56 & 0.50 & 0.33 & 0.47 & 1.76 & 0.85 \\
\hline Haiti & 1 & 1.00 & & 0.00 & & 1.00 & \\
\hline Honduras & 33 & 0.48 & 0.51 & 0.27 & 0.45 & 1.70 & 0.68 \\
\hline Mexico & 1290 & 0.50 & 0.50 & 0.27 & 0.44 & 1.92 & 0.91 \\
\hline Nicaragua & 13 & 0.62 & 0.51 & 0.38 & 0.51 & 1.69 & 0.86 \\
\hline Panama & 16 & 0.69 & 0.48 & 0.06 & 0.25 & 1.75 & 0.78 \\
\hline Paraguay & 16 & 0.38 & 0.50 & 0.19 & 0.40 & 1.94 & 1.00 \\
\hline Peru & 106 & 0.58 & 0.50 & 0.25 & 0.43 & 1.64 & 0.86 \\
\hline Puerto Rico & 75 & 0.56 & 0.50 & 0.27 & 0.45 & 1.80 & 0.89 \\
\hline Dominican Republic & 32 & 0.56 & 0.50 & 0.25 & 0.44 & 2.13 & 1.10 \\
\hline
\end{tabular}

\section{Analysis}

To address our primary research question, we studied the descriptive statistics for the use of each family and business governance structure or policy. Means below 2.5 were interpreted as indicating low levels of use of the governance practice or structure. Means between 2.6 and 3.5 indicated medium levels of use of governance practices or structures. Finally, means above 3.5 signaled high levels of use of governance structures and practices. To test the relationship between governance mechanisms and financial performance we analysed our data using hierarchical regression. In step 1 we entered the controls (i.e., industry, company age, number of employees, and founder control). In step 2 we entered the main effects for family and business governance. We evaluated the significance of each step with the change in $F(\Delta F)$ and interpreted betas with $\mathrm{t}$-values.

Table 2. Descriptive Statistics and Bivariate Correlations of Combined Data

\begin{tabular}{|c|c|c|c|c|c|c|c|c|c|}
\hline Variable & $\mathbf{M}$ & SD & 1 & 2 & 3 & 4 & 5 & 6 & 7 \\
\hline 1. Sales & 1.64 & 0.85 & & & & & & & \\
\hline 2. Family Governance & 2.10 & 1.03 & $0.152 * *$ & & & & & & \\
\hline 4. Company Age & 24.99 & 18.69 & $0.310^{* *}$ & $0.052 *$ & $0.111^{* *}$ & & & & \\
\hline 5. Employees & 1.86 & 0.91 & $0.646^{* *}$ & $0.168^{* *}$ & $0.379 * *$ & $0.404 * *$ & & & \\
\hline 8. Manufacturing & 0.27 & 0.44 & $0.162 * *$ & $0.044^{*}$ & $0.048^{*}$ & $0.195^{* *}$ & $0.224 * *$ & $0.145^{* *}$ & $-0.476 * *$ \\
\hline
\end{tabular}

Note: $\mathrm{N}=2287 .{ }^{* *} \mathrm{p}<0.01 ;{ }^{*} \mathrm{p}<0.05$ 


\section{Results}

Table 2 shows the mean and standard deviations and bivariate correlations for the combined data. We first explored our research question regarding the likelihood of small and medium family businesses using formal family and business governance mechanisms. Given that all of the means for likelihood of use were below 2.5, our results show that the family businesses in our sample expressed a low likelihood of using formal governance practices (See Table 3). On the family governance side, family firms were not likely to have a family council, stock transfer criteria, or conflict management policies. However, having formal policies for the governance of the business-family relationship was more common. On the business side, family businesses were not very likely to have either an executive or a management team. However, they were more likely to have formal policies for business procedures, and a business plan. It is important to note that none of the means indicating the use of policies were above 2.5 on our scale.

Table 3. Descriptive Statistics for Likelihood of Use of Family and Business Governance Mechanisms

\begin{tabular}{lcc}
\hline \multicolumn{1}{c}{ Variable } & Mean & SD \\
\hline FG - The family has a formal family council & 1.81 & 1.20 \\
FG - The family has formal written family policies & 2.29 & 1.36 \\
to manage business-family relationships & & \\
FG - The family has formal stock transfer criteria & 2.12 & 1.40 \\
FG - The family has policies for conflict management & 2.18 & 1.32 \\
BG - The business has written policies for business & 2.44 & 1.41 \\
procedures & & \\
BG - The business has a formal business board & 1.85 & 1.28 \\
BG - The business has a formal management team & 1.84 & 1.26 \\
BG - The business has a written business plan & 2.28 & 1.47 \\
\hline
\end{tabular}

Note: FG - Family Governance

$\mathrm{BG}$ - Business Governance

Regression analysis provides some support for our hypotheses. After accounting for the controls, the addition of the main effects in step 2 significantly increased the explained variance in financial performance $(\Delta F=$ 19.218, $p<.001$ ). As reported on Table 4 , the beta for use of formal business governance mechanisms was positive and significant $(\beta=.122, p<.001)$, supporting hypothesis 2 insofar as having formal business governance mechanisms is positively related to financial performance in family firm SMEs. However, the beta for use of formal family governance mechanisms was negative and not significant $(\beta=-.024, p>.05)$, failing to support hypothesis 1 . The overall variance explained was $44 \%$ (adjusted $R^{2}=.43$ ).
Table 4. Hierarchical Regression Analysis for Financial Performance

\begin{tabular}{lcc}
\hline \multicolumn{1}{c}{ Variable } & Model 1 & Model 2 \\
\hline Manufacturing & -0.077 & -0.025 \\
Service & $-0.081^{* * *}$ & $-0.089^{* * *}$ \\
Company Age & $0.049^{* *}$ & $0.054^{* *}$ \\
Number of Employees & $0.62^{* * *}$ & $0.577^{* * *}$ \\
Founder Control & -0.015 & 0.003 \\
& & \\
Family Governance & & -0.024 \\
Business Governance & & $0.122^{* * *}$ \\
& & \\
$F$ & $335.14 * * *$ & $248.73^{* * *}$ \\
$\Delta F$ & & $19.218^{* * *}$ \\
$R^{2}$ & 0.42 & 0.44 \\
$\Delta R^{2}$ & & 0.02 \\
Adjusted $R^{2}$ & 0.42 & 0.43 \\
\hline
\end{tabular}

Note: Model statistics are standardized betas.

$* \mathrm{p}<0.05 * * \mathrm{p}<0.01 * * * \mathrm{p}<0.001$.

\section{Discussion}

Previous research has underscored the importance of formal governance in the continuity and viability of family businesses (Miller \& Le Breton-Miller, 2006; Steier et al., 2015; Suess 2014). Thus, there is an implied assumption that family businesses around the world can benefit from implementing governance mechanisms that can help them manage the relationship between the family and the business. Even though governance is one of the most studied topics in the family business field, most of our knowledge comes from the examination of North American and European family firms (DeMassis et al., 2012). Given the unique characteristics of Latin American family firms (Botero \& Gomez Betancourt, 2017; Vazquez et al, 2020), and the limited understanding that we have regarding the governance of small and medium family firms in Latin America, this study was developed with two goals in mind. First, we wanted to explore the likelihood of using family and business governance mechanisms in small and medium family firms. Second, we wanted to test the relationship between the use of governance mechanisms and the financial performance of these firms. Using a large dataset from 24 Latin American countries we found that the firms that participated in our study were not likely to use formal family or business governance mechanisms to manage the relationship between the family and the business. Regardless of the country (see Table 1), the means for the likelihood of use of formal family and business governance were all below the 2.5 mark on our 5-point scale. Results also indicate that after controlling for industry, company age, company size, 
and founder control, the use of formal business governance mechanisms was positively related to financial performance. However, there was no correlation between the use of family governance mechanisms and financial performance.

\section{Implications for Understanding the Use of Governance Mechanisms}

Taken together our results provide a baseline understanding regarding the use of governance mechanisms by Latin American family business SMEs. Based on our sample, it is apparent that the family businesses that participated in our study present similar behaviour to that of family businesses around the world. Previous research has suggested that as family businesses become more complex (due to firm age or company size), and there is less founder control, they are more likely to implement governance mechanisms to manage these complexities (Chrisman et al., 2004; Chrisman et al., 2018; Gersick et al., 1997). Our results seem to provide some support for this idea given that larger and older family firms were more likely to use both formal family and business governance mechanisms. Thus, it may be that our sample is more representative of companies that are still not complex enough for the owner family to have introduced more formal approaches to governance. At earlier stages of family firm development, the formality of processes is reduced (Gersick et al., 1997), which then translates into lower use of formal governance practices. In this sense, our results may reflect the characteristics of family firms that are smaller and at an earlier stage in their development.

At the same time, our results could suggest that less complex family firms use other governance mechanisms to better manage the relationships between the family and the business that we were not able to capture in our survey. Given the importance that is placed on the family in Latin America (Botero \& Gomez-Betancourt, 2017), it may be that less complex family firms use other governance mechanisms to better manage the relationships between the family and the business. For example, it may be that smaller family firms rely more on informal governance mechanisms. Thus, they may use family relationships and informal family gatherings to manage and align goals among different stakeholders and determine what to do and how to do it as a group. In this respect, our results support the work of Mustakallio et al. (2002). This work suggests that relational governance (i.e., informal governance) influences the shared vision of the family which has implications in decision-making in family firms.

Our findings regarding the lack of use of formal family and business governance mechanisms may also pro- vide a unique view as to how small and medium family businesses in Latin America make decisions regarding their businesses. Our results could indicate that family-owned SMEs in this context may be less likely to use any of these formal planning tools as a way to prepare for the continuity of the family business. Latin American countries have political and economic environments that change easily (Hoy \& Mendoza-Abarca, 2014; Lansberg \& Perrow, 1991). Thus, the cultural norm may be to avoid planning because of the perception of always having to change the plan. Therefore, the limited use of formal governance structures found in this study may be a reflection of environments that are constantly changing or in which planning is difficult.

This paper expands our understanding of the use of governance mechanisms in Latin American family firms in at least two ways. First, our work complements the work of Vazquez et al. (2020) by exploring the use of governance in small and medium family firms. In particular, our results reveal some similarities between large family firms and SMEs in the characteristics of governance models they use. Our findings show that the use of governance mechanisms by small and medium family firms is somewhat reflective of the super-familiar governance model. Particularly, in our sample, the lack of use of formal family and business governance mechanisms is consistent with a governance configuration in which the family member is at the center of decision-making. At the same time, our results also indicate that in a super-familiar governance configuration the family may not require formal governance mechanisms because they may be able to use informal sources of control that help them make decisions. Thus, our results complement the work of Vazquez et al. (2020) by suggesting that the governance configurations that have the highest family involvement may have a wider range of governance tools because they use formal and informal mechanisms that can both impact the decision-making of the firm. Second, this project enhances our understanding of governance in Latin American family firms by moving from a focus on the business side of governance (Lagos Cortes \& Botero, 2016), to a focus that includes family governance. Thus, an important contribution of this paper is that it starts to shed light on the practices that exist when exploring family governance in small and medium Latin American family firms.

\section{Implications of the use of Governance Mechanisms on Financial Performance}

Our study also has important implications for understanding the effects of using governance mechanisms in the financial performance of a family firm. Using prin- 
ciples from the agency theory, previous work has found a positive relationship between the use of governance mechanisms and the financial performance of a family firm (Chrisman et al., 2004; Schulze et al., 2001; Villalonga \& Amit, 2006). Thus, in this study we wanted to understand whether these results would be similar in a Latin American context. Our data supports the positive relationship between the use of formal business governance and the financial performance of firms. Therewith our study shows evidence that principles from the agency theory work when exploring formal business governance in Latin American family business SMEs. As suggested by agency theory, using formal governance helps align the goals among different owners, and between owners and internal stakeholders. These governance mechanisms help provide clarity to members in the family firm and facilitate their decision making regarding the use and deployment of resources. This, in turn, helps in the financial performance of the firm. In this context, a material contribution of this study is that it provides initial evidence of the importance of using formal governance in small and medium family firms in Latin America.

Although we predicted similar results for the use of formal family governance mechanisms, we did not find support for the relationship between the use of formal family governance mechanisms and financial performance. Our results show that the use of formal family governance was not related to the financial performance of the family firm. These results failed to replicate the findings of Berent-Braun \& Uhlaner (2012). It may be that in our case, the companies were not big enough or did not have the complexity to necessitate these formal mechanisms. Previous work by Suess (2014) asserts that the sustainability of a family business depends in part on whether the family can be a source of competitive advantage or an obstacle to the continuity of the firm. She argues that family governance helps a family organise itself and the way it relates to the business. In line with this work, we believe that this paper provides the first step to better understand the role that formal family governance has in the performance of a family firm. Given the prevalence of a family centred culture (Botero \& Gomez Betancourt, 2017), and cultural norms in Latin America that do not promote formal planning (Hoy \& Mendoza-Abarca, 2014), it may be that in the family system business owning families use informal governance mechanisms as a way to control the relationships among family members, and between the family and the business. In this regard a contribution of this project is that it shows that in volatile environments formal mechanisms for governing the family do not seem to impact the financial performance of family firms.
Results from our study also continue to increase our understanding of heterogeneity in family firms. Chua et al. (2012) affirm that family firms are not homogeneous and are likely to differ in multiple ways. Thus, we believe that our results shed light onto how Latin American family firms differ from family firms from other parts of the world, and how they differ amongst themselves. In this respect, one aspect that seems unique regarding small and medium family firms in Latin America is that their financial performance is not positively related to the use of formal family governance. This is very different from the sample from the Netherlands used by Berent-Braun \& Uhlaner (2012), in which there was a positive relationship between formal family governance and financial performance. This provides some evidence that country culture can come between family firms with regard to the impact of using formal family governance on financial performance. Our results also point to differences between the use of formal governance mechanisms due to the size of the firm. Thus, our results continue to enhance our understanding of the importance of considering size as a source of heterogeneity in family firms.

\section{Implications for Practice}

Our findings have two important implications for practice. First, our findings indicate that formal family governance structures that are being used in other countries may not be as prevalent in Latin American small and medium family firms. For practitioners this means that we need to consider the broader cultural context with its norms to better understand which governance practices may be most useful and impactful for family firms for their sustainability. For consultants and family business managers this means that an important role they have is to understand the family and the cultural context that are in play to see which practices are more likely to fit families in their specific region of the world.

A final implication of these results for practitioners is that consultants and family business managers have a very important role in furthering the development of research regarding family governance in Latin American family firms. In particular, through their observations they can help capture aspects of family and business governance that are currently not being captured by the practices that are being adapted from other cultures.

\section{Strengths and Limitations}

The biggest strength of this project is that it is one of the first studies that explores family governance in small and medium Latin American family firms. This is very important because it provides a baseline for future exploration 
of family governance in this and other cultural contexts. Additionally, it provides some evidence of the importance of formal business governance mechanisms and how they impact the financial performance of a firm. At the same time, this paper has several limitations. One important limitation is the nature of our sample. Our study is based on a convenience sample. Thus, our sample may not be representative of the complete population of small and medium family firms in Latin America. However, given that there are no public sources of data to capture the characteristics of the population of family firms, this sample can serve as an initial picture of the descriptive information regarding small and medium private family firms in this region. We believe that future research could use alternative sources of data to explore similar ideas and determine whether these results can be replicated with other datasets.

A second limitation stems from the limited information that we had from the companies participating in our sample regarding the characteristics of family and business systems. In particular, we did not have information regarding the development stage of the business, family size, degree of family involvement in the business, or whether the family-owned multiple businesses. All of these factors could play a role in the choices of family and business governance mechanisms to be used in the family and business systems (Suess, 2014). With this in mind, we believe that future research needs to collect more descriptive information regarding the sample to be able to explore other factors that also play a role in governance choices of small and medium family firms.

A third limitation of our study is that our data was collected cross-sectionally. Thus, inferences of causality are difficult to make. In particular, we are not able to determine whether governance mechanisms drive performance or performance drives the implementation of governance mechanisms. Consequently, future research needs to collect data at multiple points in time to be able to determine the temporal order of variables. It would also be useful to complement our quantitative results with qualitative exploration of what Latin American families do to govern their family and business systems and why they make the choices that they make. This could shed some light on the reason why the families in our sample were not as likely to use the formal governance mechanisms that we explored.

\section{Conclusion}

Continuity is one of the biggest challenges that family businesses face. In an attempt to foster a greater chance for the future viability of a family business, family and business governance provide a way to help business families consider their future. This project explored the prevalence of using family and business formal governance mechanisms and their effects on the financial performance of a firm. Our results suggest that small and medium family firms in this study were not likely to use governance mechanisms. However, using formal business governance mechanisms was related to higher financial performance. Based on these results, it seems that Latin American small and medium family firms may use other forms of governance to manage the relationship between the family and the business. Future research should further explore the temporal relationships between governance mechanisms and family/business characteristics to better understand how these processes influence one another.

\section{Acknowledgements}

A previous version of this paper was the runner-up for the 2019 Adalberto Viesca Sada Award for Family Business Research in Latin America.

\section{References}

Aguilera, R. V., \& Crespi-Cladera, R. (2012). Firm family firms: Current debates of corporate governance in family firms. Journal of Family Business Strategy, 3(2), 66-69.

Aguilera, R. V., \& Jackson, G. (2003). The cross-national diversity of corporate governance: Dimensions and determinants. Academy of Management Review, 28(3), 447-465.

Aguilera, R. V., \& Jackson, G. (2010) Comparative and international corporate governance. The Academy of Management Annals, 4(1), 485-556.

Aronoff, C. E., Astrachan, J. H., \& Ward, J. L. (1998). Developing family business policies: Your guide to the future (Family Business Leadership Series 11). Business Owner Resources, Marietta, GA.

Berent-Braun, M. M., \& Uhlaner, L. M. (2012). Family governance practices and team building: Paradox of the enterprising family. Small Business Economics, 38(1), 103-119.

Berrone, P., Cruz, C., \& Gómez-Mejía, L.R. (2012). Socioemotional wealth in family firms: Theoretical dimensions, assessment approaches and agenda for future research. Family Business Review, 25, 258-279.

Brenes, E. R., Madrigal, K., \& Molina-Navarro, G. E. (2006). Family business structure and succession: Critical topics in Latin American experience. Journal of Business Research, 59(3), 372-374. 
Brenes, E. R., Madrigal, K., \& Requena, B. (2011). Corporate governance and family business performance. Journal of Business Research, 64(3), 280-285.

Botero, I. C., \& Gomez Betancourt, G. (2017). Governance Structures and family firms and their use in Latin America. In F. W Kellermanns \& F. Hoy (Eds.), Family Business Companion (pp. 549-566). Routledge.

Botero, I. C., \& Velez, D. G. (2019). Ownership structure and governance in Latin American family firms. In C. G. Müller, I. C. Botero, Discua Cruz, A. \& R. Subramanian (Eds.), Family firms in Latin America (pp.1924). Routledge.

Briano-Turrent, G. d. C., \& Poletti-Hughes, J. (2017). Corporate governance compliance of family and non-family listed firms in emerging markets: Evidence from Latin America. Journal of Family Business Strategy, 8(4), 237-247.

Cadbury, S. A. (2000). The corporate governance agenda. Corporate Governance: An International Review, 8(1), 7-15.

Carlock, R. S. \& Ward, J. L. (2001) Strategic planning for the family businesses - Parallel planning to unify the family business. Palgrave.

Castrillo Lara, L. Á., \& San Martín Reyna, J. M. (2007). La propiedad familiar como mecanismo de gobierno disciplinador de la dirección en las empresas mexicanas: una evidencia empírica. Contaduría y Administración, (222), 59-82.

Chrisman, J. J., Chua, J. H., Le Breton-Miller, I., Miller, D., \& Steier, L. P. (2018). Governance mechanisms and family firms. Entrepreneurship Theory and Practice, 42(2), 171-186

Chrisman, J. J., Chua, J. H., \& Litz, R. A. (2004). Comparing the agency costs of family and non-family firms: Conceptual issues and exploratory evidence. Entrepreneurship Theory and practice, 28(4), 335-354.

Chua, J. H., Chrisman, J. J., Steier, L. P., \& Rau, S. B. (2012). Sources of heterogeneity in family firms: An introduction. Entrepreneurship Theory and Practice, 36(6), 1103-1113.

Colli, A. (2003). The history of family business 1850 2000. Cambridge University Press.

De Massis, A., Sharma, P., Chua, J., \& Chrisman, J. (2012). Family business studies an annotated bibliography. Edward Elgar Publishing Inc.

Daily, C. M., Dalton, D. R., \& Cannella Jr, A. A. (2003). Corporate governance: Decades of dialogue and data. Academy of Management Review, 28(3), 371382.

Davis, P. (1983). Realizing the potential of the family business. Organizational Dynamics, 12, 47-56.
Debicki, B. J., Matherne III, C. F., Kellermanns, F. W., \& Chrisman, J. J. (2009). Family business research in the new millennium: An overview of the who, the where, the what, and the why. Family Business Review, 22(2), 151-166.

Eddleston, K. A., \& Kellermanns, F. W. (2007). Destructive and productive family relationships: A stewardship theory perspective. Journal of Business Venturing, 22, 545-565.

Espinoza Aguiló, T. I. \& Espinoza Aguiló, N. F. (2012). Family business performance: Evidence from Mexico. Cuadernos de Administración, 25(44), 39-61.

Gallo, M. A. \& Tomaselli, S. (2006). Formulating, implementing, and maintaining family protocols. In P. Z. Poutziouris, K. X. Smyrnios \& S.B. Klein (Eds.), Handbook of Research on Family Business (pp. 298316). Edward Elgar.

Gersick, K.E. (2015). Essay on practice: Advising family enterprise in the fourth decade. Entrepreneurship Theory and Practice, 39, 1433-1450.

Gersick, K. E., Davis, J. A., McCollom Hampton, M., \& Lansberg, I. (1997). Generation to generation: Life cycles of the family business. Harvard Business Press.

Gersick, K. E., \& Feliu, N. (2014). Governing the family enterprise: Practices, performance, and research. In L. Melin, M. Nordqvist, \& P. Sharma (Eds.), The Sage Handbook of Family Business (pp. 196-225). Sage.

Gómez-Mejía, L. R., Haynes, K. T., Núñez-Nickel, M., Jacobson, K. J., \& Moyano-Fuentes, J. (2007). Socioemotional wealth and business risks in family-controlled firms: Evidence from Spanish olive oil mills. Administrative Science Quarterly, 52(1), 106137.

Howorth, C., Rose, M., Hamilton, E., \& Westhead, P. (2010). Family firm diversity and development: An introduction. International Small Business Journal, 28(5), 437-451.

Hoy, F., \& Mendoza-Abarca, K. (2014). Latin America. In S. M. Carraher \& D. H. B. Welsh (Eds.) Global Entrepreneurship ( $2^{\text {nd }}$ Ed., pp. 293-312). Kendall Hunt Publishing.

Husted, B. W., \& de Sousa-Filho, J. M. (2019). Board structure and environmental, social, and governance disclosure in Latin America. Journal of Business Research, 102, 220-227.

International Family Enterprise Research Academy (IFERA). (2003). Family businesses dominate: International Family Enterprise Research Academy (IFERA). Family Business Review, 16(4), 235-240.

Jaffe, D. T., \& Lane, S. H. (2004). Sustaining a family dynasty: Key issues facing complex multigenerational 
business-and investment-owning families. Family Business Review, 17(1), 81-98.

Jensen, M. C. (1986). Agency costs of free cash flow, corporate finance, and takeovers. The American Economic Review, 76(2), 323-329.

Jensen, M. C., \& Meckling, W. H. (1976). Theory of the firm: Managerial behavior, agency costs and ownership structure. Journal of Financial Economics, 3(4), 305-360.

Kellermanns, F. W., \& Eddleston, K. A. (2004). Feuding families: When conflict does a family firm good. Entrepreneurship Theory and Practice, 28, 209-228.

Lagos Cortes, D., \& Botero, I. C. (2016) Corporate governance in family businesses from Latin America, Spain and Portugal: A review of the literature. Academia. Revista Latinoamericana de Administración, 29(3), 231-254.

Lansberg, I., \& Perrow, E. (1991). Understanding and working with leading family businesses in Latin America, Family Business Review, 4(2), 127-147.

Lopez-Fernandez, M. C., Serrano-Bedia, A. M., PerezPerez, M., Hernandez-Linares, R. \& Palma-Ruiz, M. (2017). A review of the academic literature on family business in Spanish. In F. W. Kellermanns \& F. Hoy (Eds.), Family Business Companion (pp. 522-548). Routledge.

Lopez Vergara, M. P., Gómez-Betancourt, G., \& Betancourt Ramírez, J. B. (2011). Factores que influyen en la participación de la mujer en cargos directivos y órganos de gobierno de la empresa familiar colombiana. Cuadernos de Administración, 24(42), 253-274.

Machuga, S., \& Teitel, K. (2009). Board of director characteristics and earnings quality surrounding implementation of a corporate governance code in Mexico. Journal of International Accounting, Auditing and Taxation, 18(1), 1-13.

Miller, D., \& Le Breton-Miller, I. (2006). Family governance and firm performance: Agency, stewardship, and capabilities. Family Business Review, 19(1), 73-87.

Morck, R. \& Steier, L. (2005). The global history of corporate governance: An introduction. In R. Morck (Ed.), The history of corporate governance around the world: Family business groups to professional managers (pp. 1-64). Chicago University Press \& National Bureau of Economic Research.

Montemerlo, D., \& Ward, J. L. (2011) The family constitution-Agreements to secure and perpetuate your family and your business. Palgrave Macmillan.

Müller, C. G., Botero, I. C., Cruz, A. D., \& Subramanian, R. (Eds.). (2019). Family firms in Latin America. Routledge.
Mustakallio, M., Autio, E., \& Zahra, S. A. (2002). Relational and contractual governance in family firms: Effects on Strategic decision making. Family Business Review, 15(3), 205-222.

Nicholson, E. (2011). Discovering Latin America and its family businesses. Tharawat Magazine. https://www. tharawat-magazine.com/family-business-boards/latin-america-family-business/

Nicholson, L. A. (2015). Family-owned businesses-the seat of entrepreneurship: The case of three english-speaking Caribbean countries. Journal of Eastern Caribbean Studies, 40(2), 1-27.

Nordqvist, M., Marzano, G., Brenes E. R., Jimenez, G., \& Fonseca-Paredes, M. (2011). Understanding entrepreneurial family businesses in uncertain environments: The case of Latin America. In M. Nordqvist, G. Marzano, E. R. Brenes, G. Jimenez, \& M. Fonseca-Paredes (Eds.), Understanding entrepreneurial family businesses in uncertain environments: Opportunities and research in Latin America. Edward Elgar.

Olson, P. D., Zuiker, V. S., Danes, S. M., Stafford, K., Heck, R. K., \& Duncan, K.A. (2003). The impact of the family and the business on family business sustainability. Journal of Business Venturing, 18 (5), 639666.

Parada, M. J., Müller, C., \& Gimeno, A. (2016). Family firms in Ibero-America: An introduction. Academia. Revista Latinoamericana de Administración, 29(3), 219-230

Peng, M. W., Sun, W., Vlas, C., Minichilli, A., \& Corbetta, G. (2018). An institution-based view of large family firms: A recap and overview. Entrepreneurship Theory and Practice, 42(2), 187-205.

Pieper, T. (2003). Corporate governance in family firms: A literature review (Working Paper Series 2003/97/ IIFE). INSEAD.

Pieper, T. M., Astrachan, J. H., \& Manners, G. E. (2013). Conflict in family business: Common metaphors and suggestions for intervention. Family Relations, 62(3), 490-500.

Santiago-Castro, M., \& Brown, C. J. (2007). Ownership structure and minority rights: A Latin American view. Journal of Economics and Business, 59(5), 430442.

Sáenz-Gonzalez, J. \& García-Meca, E. (2014). Does corporate governance influence earnings management in Latin American markets? Journal of Business Ethics, 121(3), 419-440.

Saito, R., \& Di Miceli da Salveira A. (2010). The relevance of tag along rights and identity of controlling shareholders for the price spreads between dual-class 
shares: The Brazilian case. BAR-Brazilian Administration Review, 7(1), 1-21.

Schulze, W. S., Lubatkin, M. H., Dino, R. N., \& Buchholtz, A. K. (2001). Agency relationships in family firms: Theory and evidence. Organization Science, (12), 99-116.

Sharma, P., \& Chua, J. H. (2013). Asian family enterprises and family business research. Asian Pacific Journal of Management, 30(3), 641-656.

Stafford, K., Duncan, K. A., Danes, S. M., \& Winter, M. (1999). A research model of sustainable family business. Family Business Review, 12(3), 197-208.

Steier, L. P., Chrisman, J. J., \& Chua, J. H. (2015). Governance challenges in family businesses and business families. Entrepreneurship Theory and Practice, 39(6), 1265-1280.

Suess, J. (2014). Family governance-Literature review and the development of a conceptual model. Journal of Family Business Strategy, 5(2), 138-155.

Uhlaner, L. M. (2006). Business family as a team: Underlying force for sustained competitive advantage. In P. Poutziouris, K. X. Smyrnios, \& S. Klein (Eds.), Handbook of Research On Family Business (pp. 125144). Edward Elgar Publishing.

Vazquez, P., Carrera, A., \& Cornejo, M. (2020). Corporate governance in the largest family firms in Latin America. Cross Cultural \& Strategic Management, 27(2), 137-163.
Villalonga, B., \& Amit, R. (2006). How do family ownership, control and management affect firm value? Journal of financial Economics, 80(2), 385-417.

Villalonga, B., Amit, R., Trujillo, M. A., \& Guzmán, A. (2015). Governance of family firms. Annual Review of Financial Economics, 7, 635-654.

Ward, J. L. (1997). Growing the family business: Special challenges and best practices. Family Business Review, 10, 323-337.

Ward, J. L. (2000). Reflections on Indian family groups. Family Business Review, 13(4), 271-278.

Watkins Fassler, K., \& Dávila Delgado, M. (2012). Reemplazos de directivos en México: de la teoría a la práctica. Contaduría y administración, 57(1), 13-28.

Yu, A., Lumpkin, G. T., Sorenson, R. L., \& Brigham, K. H. (2012). The landscape of family business outcomes: A summary and numerical taxonomy of dependent variables. Family Business Review, 25(1), 33-57.

Zellweger, T., \& Kammerlander, N. (2015). Article commentary: Family, wealth, and governance. An agency account. Entrepreneurship Theory and Practice, 39(6), 1281-1303. 